\title{
PERANCANGAN BOARD GAME EDUKASI ANTI BULLYING UNTUK ANAK SEKOLAH DASAR
}

\author{
Widyasari ${ }^{1}$, Aditya Rahman Yani ${ }^{2}$, Nia Wulandari ${ }^{3}$, Eki Cahya Imani ${ }^{4}$ \\ 1,2,3,4 Desain Komunikasi Visual, Fakultas Arsitektur dan Desain, UPN “Veteran” Jawa Timur \\ ${ }^{1}$ widyasari.dkv@upnjatim.ac.id
}

\begin{abstract}
Abstrak
Kasus bullying di Indonesia merupakan masalah sosial yang serius untuk ditindaklanjuti, terutama di kalangan anak Sekolah Dasar (SD) karena dapat memberikan dampak yang sangat buruk pada moral anak juga dapat menyakiti orang lain. Di sisi lain, guru maupun orang tua beranggapan bahwa perilaku bullying merupakan sebuah proses dari perkembangan anak sehingga belum ada tindak lanjut untuk mengatasi permasalahan bullying tersebut. Sebagai upaya untuk mengatasi kasus bullying dan menegakkan dasar hukum, larangan melakukan bullying pada anak perlu dilakukan sebagai edukasi anti bullying kepada anak SD melalui media yang dekat dengan anak yakni board game. Pesan edukasi anti bullying yang disampaikan melalui board game diharapkan dapat mempersuasi anak untuk berani bersikap positif "stop bullying" jika melihat kejadian bullying di lingkungan sekolah. Metode penelitian yang digunakan adalah metode kualitatif dengan pengumpulan data primer melalui wawancara mendalam dan data sekunder melalui studi literatur. Konsep yang disusun merupakan hasil analisis fishbone dan analisis $5 \mathrm{~W}+1 \mathrm{H}$ yakni berupa solusi kreatif board game, konsep kreatif pesan anti bullying, dan keyword "Fun Positive Learning" diterapkan pada desain komponen-komponen board game. Board game edukasi anti bullying dengan judul Berani Baik! dirancang dengan visual yang menarik dan alur permainan yang menyenangkan dalam bentuk pertanyaan sebagai studi kasus perilaku bullying di lingkungan sekolah dan pilihan jawaban sebagai pesan anti bullying kepada anak SD.
\end{abstract}

Kata kunci: anak sekolah dasar, anti bullying, board game

\begin{abstract}
The case of bullying in Indonesia is a serious social problem to be pursued, specifically among elementary school children due to badly impacting children's morals and can hurt others. On the other hand, teachers and parents thought that bullying behavior is a process of child development so that there has been no action to overcome the problem of bullying. As an effort to overcome bullying cases and enforce the essential law, the prohibition of bullying on children needs to be done as an anti-bullying education for elementary school children through board games. Anti-bullying educational messages conveyed through board games befit to persuade children to have a positive attitude to "stop bullying" when they see bullying in the school environment. This research uses a qualitative method with primary data collection through indepth interviews and secondary data through literature study. The concept compiled is the result of fishbone and $5 \mathrm{~W}+1 \mathrm{H}$ analysis in the form of creative board game solutions, creative concepts for anti-bullying messages, and the keyword "Fun Positive Learning" is applied to the design of the board game components. Anti-bullying educational board game with the title Dare to Be Good! designed with attractive visuals and fun gameplay in the form of questions as case studies of bullying in the school environment and answer choices as anti-bullying messages to elementary school children.
\end{abstract}

Keywords: anti bullying, board game, elementary school children 


\section{PENDAHULUAN}

Bullying berasal dari Bahasa Inggris, yaitu "bull" yang berarti banteng. Secara etimologi kata "bully" berarti penggertak, orang yang mengganggu pihak yang lemah, sedangkan bullying dalam Bahasa Indonesia disebut "menyakat" yang artinya mengganggu, mengusik, dan merintangi orang lain (Wiyani, 2012). Criswell (2009) dalam bukunya "Stand up for Yourself and Your Friends", menyatakan bahwa alasan seseorang melakukan tindakan bullying antara lain: rasa kesepian, sedih, marah, memiliki masalah yang tidak dapat diselesaikan, mengalami penindasan di rumah, ingin diperhatikan, tidak terlalu percaya diri, punya pengalaman diperlakukan buruk sebelumnya, dan tidak menyadari bahwa menyakiti hati orang adalah salah.

Menurut Coloroso (2006) perilaku bullying dapat dikelompokkan menjadi empat bentuk, yakni: 1) Bullying relasional: Bullying relasional paling sulit dideteksi dari luar. Contoh bulying relasional adalah perilaku atau sikap-sikap yang tersembunyi seperti pandangan yang agresif, lirikan mata, helaan nafas, cibiran, tawa mengejek, dan bahasa tubuh yang mengejek; 2) Bullying verbal: Bullying verbal biasanya menjadi awal dari perilaku bullying yang lainnya. Contoh bullying verbal adalah julukan nama, celaan, kritikan kejam, penghinaan, penyataan-pernyataan pelecehan seksual, teror, dan gosip; 3) Bullying fisik: Bullying fisik paling tampak dan mudah untuk diidentifikasi. Contoh bullying fisik adalah memukuli, menendang, menampar, mencekik, menggigit, mencakar, meludahi, dan merusak serta menghancurkan barang-barang milik anak yang tertindas. 4) Cyber-Bullying: Cyber-bullying dilakukan pelakunya melalui sarana elektronik seperti komputer, handphone, internet, website, chatting room, e-mail, SMS, dan sebagainya dengan bentuk mengintimidasi, menyakiti, atau menyudutkan.

Kasus bullying semakin hari semakin marak terjadi di Indonesia dan menjadi masalah sosial yang serius, terutama di kalangan anak Sekolah Dasar yang menjadi mayoritas terjadinya kasus bullying. Erikson dalam Santrock (2009) menjelaskan bahwa anak usia Sekolah Dasar berada pada tahap industry vs inferiority di mana pada tahap ini anak telah memasuki dunia sekolah. Pada tahap ini dapat dikatakan bahwa anak memiliki jiwa kompetitif yang tinggi dan berfokus pada pencapaian prestasi dan akan berusaha semaksimal mungkin agar dapat lebih unggul dibandingkan teman-temannya. Berdasarkan data Komisi Perlindungan Anak Indonesia (KPAl), kasus bullying yang terjadi di Sekolah Dasar pada tahun 2016 terdapat 81 korban dan 93 pelaku, tahun 2017 terdapat 129 korban dan 117 pelaku, tahun 2018 terdapat 107 korban dan 127 pelaku (Instagram kpai_official, 2020). Data KPAI juga menyebutkan bahwa perilaku bullying menempati urutan ke-empat dalam kasus kekerasan anak yang terjadi di Indonesia (Hendrian, 2018).

Di sisi lain, perilaku bullying tidak ditanggapi secara serius oleh guru maupun orang tua. Mereka beranggapan bahwa perilaku bullying merupakan sebuah proses dari perkembangan anak dan belum ada tindak lanjut untuk mengatasi permasalahan bullying tersebut. Banyak anak-anak korban bullying yang sudah melapor kepada guru atau kepada orang tua, tetapi respon yang didapat hanya sebatas kata-kata agar tidak menanggapi cemoohan itu. Banyak orang tua yang tidak menggubris keluhan anak 
mereka yang dibully oleh teman-temannya. Biasanya orang tua hanya mengatakan kepada anak supaya tidak menanggapi bullyan teman-teman, sementara di sisi lain tidak semua korban tahan dengan bullyan tersebut (Instagram kpai_official, 2020). Hal ini dapat mengakibatkan perilaku bullying sering terjadi secara berulang-ulang baik di lingkungan sekolah maupun di lingkungan tempat tinggal.

Dasar Hukum larangan melakukan bullying kepada anak telah diatur dalam UndangUndang No. 35 Tahun 2014 tentang perlindungan anak yakni dilarang menempatkan, membiarkan, melakukan, menyuruh melakukan, atau turut serta melakukan kekerasan terhadap anak. Sehingga dalam konteks ini sebagai upaya untuk menegakkan Dasar Hukum tersebut perlu dilakukan edukasi anti bullying kepada anak Sekolah Dasar. Edukasi ini difokuskan pada penyampaian pesan anti bullying tentang sikap positif yang dapat dilakukan oleh anak-anak jika melihat kejadian bullying di lingkungan sekolah. Pesan anti bullying bertujuan untuk meningkatkan keberanian dan rasa percaya diri pada anak, berdiri tegak, dan mengatakan "stop it" pada perilaku bullying. Pesan anti bullying agar dapat tersampaikan secara efektif kepada anak-anak, maka perlu dikemas melalui media yang menarik dan dekat dengan anak-anak, salah satunya melalui melalui media board game.

Board game (permainan papan) adalah jenis permainan yang dimainkan dengan papan sebagai alat utama permainannya (Najib, 2018:10). Board game menjadikan sebuah bidang sebagai komponen utama dari permainan tersebut dan dimainkan oleh lebih dari satu orang sehingga mampu meningkatkan interaksi sosial. Board game merupakan permainan yang fleksibel, dalam artian berbagai jenis tema pembelajaran (edukasi) mampu diterapkan dalam board game. Board game menyediakan aktivitas yang sifatnya rekreatif, dimainkan secara berkelompok, dan dapat mengarahkan para pemain bermain secara kompetitif, kooperatif, dan kolaboratif. Board game dapat menjadi media yang efektif karena anak-anak sangat menyukai permainan, kegiatan bermain, interaktifitas, dan hal-hal yang menyenangkan. Menurut Soefandi (2015:18) menyebutkan bahwa bermain memiliki berbagai fungsi untuk perkembangan dan pertumbuhan anak, seperti: latihan pengambilan keputusan, memilih, mandiri, tuntas, kreativitas, percaya diri, pengembangan intelektual, pengembangan bahasa, dan sebagainya. Melalui perancangan board game edukasi anti bullying untuk anak Sekolah Dasar diharapkan dapat menjadi media yang efektif, menarik, dan dapat mempersuasi anak-anak untuk berani bersikap positif "stop bullying" jika melihat kejadian bullying di lingkungan sekolah.

\section{METODE PENELITIAN}

\subsection{Pendekatan Penelitian}

Metode penelitian yang digunakan dalam perancangan board game edukasi anti bullying ini adalah metode penelitian kualitatif yang bersifat fleksibel dan dapat berubah-ubah sesuai dengan kondisi lapangan. Data yang diperoleh melalui metode penelitian kualitatif adalah data kualitatif dalam bentuk teks, dokumen, gambar, foto, artefak, atau objek-objek lainnya yang ditemukan di lapangan selama penelitian dilakukan (Sarwono, 2007:95). 


\subsection{Prosedur Penelitian}

Langkah-langkah yang digunakan untuk menyusun penelitian ini adalah sebagai berikut:

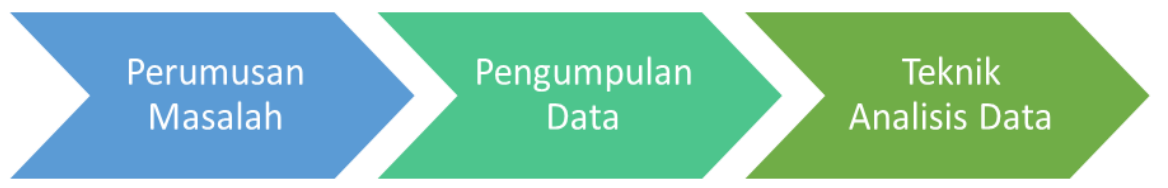

Gambar 1. Prosedur Penelitian

[Sumber: Dokumentasi Penulis]

Tahap pertama adalah perumusan masalah. Peneliti mencari sebuah fenomena atau permasalahan yang sedang terjadi di masyarakat yang urgent untuk diselesaikan dan dapat menjadi sebuah landasan dalam penyusunan penelitian. Fenomena atau permasalahan yang telah ditemukan kemudian diobservasi dan dibedah lebih mendalam untuk dicari kebenaran akan adanya fenomena atau permasalahan tersebut. Selanjutnya data yang telah diperoleh akan dianalisis lebih mendalam untuk disusun sebagai rumusan masalah, sehingga ditemukan sebuah solusi yang dapat digunakan. Solusi yang ditemukan adalah memberikan edukasi anti bullying kepada anak Sekolah Dasar melalui media board game sebagai output dalam penelitian ini.

Tahap kedua yaitu pengumpulan data. Pengumpulan data yang dilakukan pada penelitian ini adalah berupa pengumpulan data primer dan pengumpulan data sekunder. Data primer dapat diperoleh melalui wawancara mendalam (depth interview), sedangkan data sekunder dapat diperoleh melalui studi literatur. Data primer adalah data yang diperoleh atau dikumpulkan langsung di lapangan oleh orang yang melakukan penelitian atau yang bersangkutan (Hasan, 2002:82). Data primer merupakan data yang didapatkan secara langsung melalui sumbernya dengan menggunakan berbagai cara atau metode. Data primer dalam penelitian ini adalah diperoleh melalui wawancara mendalam (depth interview).

Wawancara merupakan percakapan yang dilakukan oleh dua pihak dengan maksud tertentu, antara pewawancara (interviewer) yang mengajukan pertanyaan dengan terwawancara (interview) yang memberikan jawaban atas pertanyaan (Moleong, 2010:186). Pada penelitian ini kegiatan wawancara mendalam dilakukan kepada empat narasumber yang berbeda untuk pengumpulan data primer, yakni:

a. Wawancara kepada guru Sekolah Dasar di Surabaya untuk penggalian data perilaku bullying yang sering dilakukan anak-anak di sekolah dan upaya edukasi anti bullying yang pernah dilakukan oleh pihak sekolah.

b. Wawancara kepada psikolog anak untuk mengetahui solusi yang dapat diterapkan untuk menangani perilaku bullying pada anak berdasarkan keilmuan psikologi.

c. Wawancara kepada anak-anak yang bersekolah di Sekolah Dasar Negeri atau Sekolah Dasar Swasta di Surabaya untuk mengetahui tingkat ketertarikan mereka terhadap board game dan bagaimana perilaku mereka terhadap teman-teman sebaya di sekolah. 
d. Wawancara kepada praktisi board game yakni salah satu creator board game Indonesia, untuk penggalian data terkait dengan perancangan board game yang menarik dan menyenangkan untuk dimainkan oleh anak-anak.

Data sekunder adalah data yang diperoleh atau dikumpulkan oleh orang yang melakukan penelitian dari sumber-sumber yang telah ada (Hasan, 2002:58). Data sekunder memuat berbagai informasi yang berkaitan dengan penelitian yakni edukasi anti bullying untuk anak Sekolah Dasar dan media board game yang dapat diperoleh melalui dokumentasi, buku, jurnal, dan artikel yang dapat diakses melalui internet maupun dalam bentuk fisik.

Tahap ketiga analisis data. Analisis data merupakan suatu proses menata, menyetrukturkan, dan memaknai data yang tidak beraturan (Daymon, 2002:367). Analisis data yang digunakan pada penelitian ini adalah analisis data kualitatif dengan proses sistematis yang terus-menerus berlangsung bersamaan dengan pengumpulan data. Analisis data kualitatif pada penelitian ini berupa analisis fishbone dan analisis $5 \mathrm{~W}+1 \mathrm{H}$. Analisis fishbone merupakan metode analisis yang berasal dari sebab dan akibat (cause and effect) pada sebuah kasus penelitian (Wibisono, 2020:101). Sesuai dengan namanya, model analisis ini berbentuk "tulang ikan". Analisis fishbone ini sebenarnya digunakan untuk mendeskripsikan data awal penelitian, karena sifatnya yang menguraikan sifat-sifat dalam metode penelitian dan menekankan pada sebab akibat. Hasil dari analisis dengan menggunakan analisis fishbone adalah menyusun solusi kreatif untuk merancang board game edukasi anti bullying.

Analisis $5 \mathrm{~W}+1 \mathrm{H}$ merupakan metode analisis yang menggunakan rumusan kalimat tanya What (Apa), Why (Mengapa), Who (Siapa), Where (Di mana), When (Kapan), dan How (Bagaimana). Kalimat tanya $5 \mathrm{~W}+1 \mathrm{H}$ digunakan untuk mengumpulkan informasi agar dapat memperoleh cerita yang utuh tentang suatu hal. Masing-masing kalimat tanya $5 \mathrm{~W}+1 \mathrm{H}$ mempunyai fungsi yang berbeda, What (Apa) untuk menunjukkan benda, Why (Mengapa) untuk menunjukkan keterangan, Who (Siapa) dapat diibaratkan tokoh dalam cerita, Where (Di mana) untuk menunjukkan tempat kejadian, When (Kapan) dapat disebut waktu kejadian, dan How (Bagaimana) untuk menunjukkan suatu cara (Misrah, 2013). Dalam penelitian ini, hasil analisis data dengan menggunakan kalimat tanya $5 \mathrm{~W}+1 \mathrm{H}$ digunakan untuk menyusun konsep kreatif pesan anti bullying yang disampaikan kepada anak Sekolah Dasar.

\section{HASIL DAN PEMBAHASAN}

\subsection{Analisis Data dan Konsep Kreatif Pesan}

Data primer dan data sekunder yang telah dikumpulkan kemudian dilakukan analisis dengan menggunakan diagram fishbone seperti pada Gambar 2. Dari hasil analisis tersebut kemudian disusun solusi kreatif untuk merancang board game pada penelitian ini. 


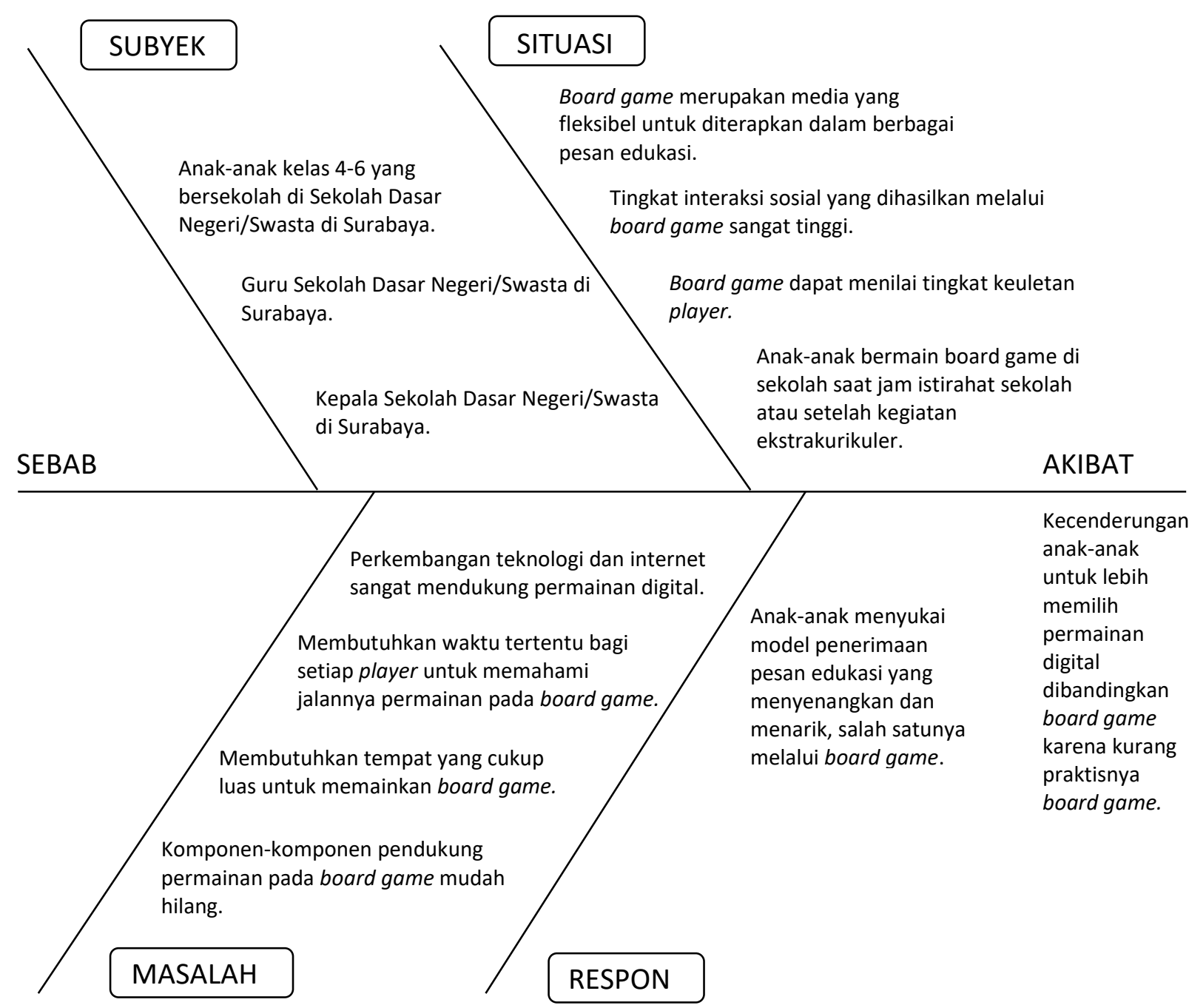

Gambar 2. Skema Analisis Data dengan Menggunakan Diagram Fishbone

[Sumber: Dokumentasi Penulis]

Solusi kreatif yang disusun untuk merancang board game edukasi anti bullying adalah 1) Merancang board game edukasi anti bullying dengan tingkat kesulitan dan standard durasi waktu penyelesaian permainan yang ideal bagi anak Sekolah Dasar. 2) Merancang board game edukasi anti bullying dengan ukuran (dimensi) yang ideal untuk dimainkan. 3) Merancang board game dengan konsep komponen-komponen yang praktis untuk meminimalisasi kehilangan komponen board game.

Board game dipilih sebagai salah satu media yang efektif untuk menyampaikan pesan edukasi kepada anak-anak karena anak-anak dapat menerima pesan edukasi dengan cara yang menyenangkan yakni bermain. Board game edukasi anti bullying untuk anak Sekolah Dasar merupakan board game yang dirancang secara efektif, menarik, dan dapat mempersuasi anak-anak untuk berani bersikap positif "stop bullying" jika melihat kejadian bullying di lingkungan sekolah. Pada Gambar 3 merupakan skema keunggulan penggunaan media board game dalam penyampaian pesan anti bullying kepada anak Sekolah Dasar berdasarkan hasil wawancara kepada praktisi board game dan psikolog anak. 


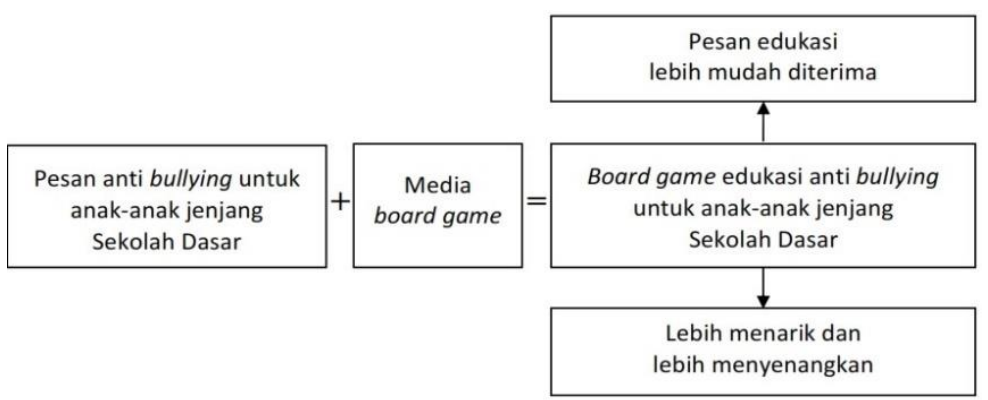

Gambar 3. Skema Keunggulan Media Board Game dalam Penyampaian Pesan Edukasi Anti Bullying kepada Anak Sekolah Dasar [Sumber: Dokumentasi Penulis]

Data primer dan data sekunder yang telah dikumpulkan selanjutnya dilakukan analisis dengan menggunakan rumusan kalimat tanya $5 \mathrm{~W}+1 \mathrm{H}$ (What, When, Where, Why, Who, How) untuk menyusun konsep kreatif pesan anti bullying yang disampaikan kepada anak Sekolah Dasar.

Tabel 1. Analisis 5W+1H untuk Menyusun Konsep Kreatif Pesan [Sumber: Dokumentasi Penulis]

\begin{tabular}{|c|c|}
\hline $5 W+1 H$ & Hasil Analisis \\
\hline \multirow[t]{3}{*}{$\begin{array}{l}\text { (What) } \\
\text { Apa saja bentuk perilaku } \\
\text { bullying yang sering } \\
\text { dilakukan oleh anak } \\
\text { Sekolah Dasar di } \\
\text { lingkungan sekolah? }\end{array}$} & $\begin{array}{l}\text { Berdasarkan hasil wawancara kepada guru Sekolah Dasar di } \\
\text { Surabaya, beberapa perilaku bullying yang sering dilakukan } \\
\text { oleh siswa-siswi di lingkungan sekolah adalah mengejek, } \\
\text { mengolok-olok dengan nama orang tua, menggojlok teman } \\
\text { yang memiliki barang baru, meminjam barang tanpa izin, } \\
\text { mengembalikan barang seenaknya sendiri, dan tidak berterima } \\
\text { kasih. }\end{array}$ \\
\hline & $\begin{array}{l}\text { Berdasarkan hasil wawancara kepada dua siswa-siswi yang } \\
\text { bersekolah di Sekolah Dasar Negeri dan Sekolah Dasar Swasta } \\
\text { di Surabaya, beberapa perilaku bullying yang sering dilakukan } \\
\text { oleh teman-teman di sekolah adalah usil, mengejek dengan } \\
\text { nama orang tua, memukul, dan memberi jebakan. }\end{array}$ \\
\hline & $\begin{array}{l}\text { Berdasarkan hasil wawancara kepada psikolog anak, beberapa } \\
\text { perilaku bullying yang sering dilakukan oleh anak Sekolah Dasar } \\
\text { adalah mengejek, mengucilkan, dan memilih milih teman } \\
\text { bermain yang setara. }\end{array}$ \\
\hline $\begin{array}{l}\text { (When) } \\
\text { Kapan pesan edukasi anti } \\
\text { bullying tepat untuk } \\
\text { disampaikan kepada anak- } \\
\text { anak? }\end{array}$ & $\begin{array}{l}\text { Berdasarkan hasil wawancara kepada salah satu guru Sekolah } \\
\text { Dasar di Surabaya dan wawancara kepada psikolog anak, pesan } \\
\text { edukasi anti bullying lebih tepat disampaikan kepada anak } \\
\text { Sekolah Dasar kelas 4-6, karena pada jenjang tersebut sudah } \\
\text { dapat menerima pemahaman yang lebih berat terhadap } \\
\text { lingkungan. }\end{array}$ \\
\hline
\end{tabular}




\begin{tabular}{|c|c|}
\hline $5 W+1 H$ & Hasil Analisis \\
\hline $\begin{array}{l}\text { (Where) } \\
\text { Di mana pesan edukasi anti } \\
\text { bullying tepat untuk } \\
\text { disampaikan kepada anak- } \\
\text { anak? }\end{array}$ & $\begin{array}{l}\text { Berdasarkan hasil wawancara kepada salah satu guru Sekolah } \\
\text { Dasar di Surabaya dan wawancara kepada psikolog anak, pesan } \\
\text { edukasi anti bullying lebih tepat disampaikan kepada anak saat } \\
\text { berada di lingkungan sekolah, karena perilaku bullying kepada } \\
\text { teman seringkali terjadi di lingkungan sekolah. Pesan edukasi } \\
\text { anti bullying disampaikan melalui media board game dan } \\
\text { terjadi interaktifitas secara langsung antara sesama anak dan } \\
\text { anak dengan pemandu (guru di sekolah). }\end{array}$ \\
\hline $\begin{array}{l}\text { (Why) } \\
\text { Mengapa mengangkat } \\
\text { edukasi anti bullying untuk } \\
\text { disampaikan kepada anak- } \\
\text { anak? }\end{array}$ & $\begin{array}{l}\text { Berdasarkan data Komisi Perlindungan Anak Indonesia (KPAl), } \\
\text { perilaku bullying pada anak Sekolah Dasar semakin hari } \\
\text { semakin meningkat dan semakin marak ditemui baik di media } \\
\text { cetak, media elektronik, maupun media sosial. Bahkan } \\
\text { kekerasan yang merupakan bentuk perilaku menyimpang ini } \\
\text { telah mengarah kepada tindak kriminal. Perilaku bullying pada } \\
\text { kalangan anak Sekolah Dasar merupakan kasus yang penting } \\
\text { untuk ditindaklanjuti karena dapat memberikan dampak yang } \\
\text { sangat buruk pada moral anak juga dapat menyakiti orang lain. } \\
\text { Sehingga sebagai upaya untuk menanggulangi kasus bullying } \\
\text { perlu dilakukan edukasi anti bullying kepada anak Sekolah } \\
\text { Dasar. }\end{array}$ \\
\hline $\begin{array}{l}\text { (Who) } \\
\text { Siapa yang menjadi } \\
\text { penerima pesan anti } \\
\text { bullying? }\end{array}$ & $\begin{array}{l}\text { Anak Sekolah Dasar kelas 4-6, Kelas sosial menengah ke atas, } \\
\text { Bersekolah di Sekolah Dasar Negeri dan Sekolah Dasar Swasta } \\
\text { di Surabaya, Senang dengan aktivitas bermain sambil belajar, } \\
\text { dan Tertarik dengan pemecahan sebuah masalah melalui } \\
\text { permainan. }\end{array}$ \\
\hline \multirow[t]{2}{*}{$\begin{array}{l}\text { (How) } \\
\text { Bagaimana bentuk edukasi } \\
\text { anti bullying yang telah } \\
\text { diterapkan di sekolah? }\end{array}$} & $\begin{array}{l}\text { Berdasarkan hasil wawancara kepada guru Sekolah Dasar di } \\
\text { Surabaya, selama ini terdapat kegiatan-kegiatan positif yang } \\
\text { sering diadakan di sekolah untuk mendukung edukasi anti } \\
\text { bullying, seperti berbagi kasih sebagai pendidikan karakter } \\
\text { peduli terhadap sesama, berbagi bekal bersama, saling } \\
\text { memberi ketika ada siswa-siswi yang tertimpa musibah, saling } \\
\text { bersedia meminjamkan barang, dan sebagainya. Jika terdapat } \\
\text { perilaku bullying pada siswa-siswi di sekolah, guru memberikan } \\
\text { edukasi dengan menyampaikan pesan positif secara oral } \\
\text { berkali-kali kepada siswa-siswi. }\end{array}$ \\
\hline & $\begin{array}{l}\text { Berdasarkan hasil wawancara kepada dua siswa-siswi yang } \\
\text { bersekolah di Sekolah Dasar Swasta dan Sekolah Dasar Negeri } \\
\text { di Surabaya, selama ini guru memberikan pesan kepada siswa- } \\
\text { siswi untuk saling berbagi dan saling membantu dengan teman- } \\
\text { teman di sekolah. Jika terdapat perilaku bullying di sekolah } \\
\text { seperti siswa-siswi bertengkar, mengejek, sikap guru adalah } \\
\text { menegur siswa-siswi yang melakukan tindakan tersebut, } \\
\text { mengancam akan melaporkan kepada kepala sekolah, dan } \\
\text { memberi hukuman untuk mengerjakan tugas di luar kelas. }\end{array}$ \\
\hline
\end{tabular}




\begin{tabular}{|l|l|}
\hline \multicolumn{1}{|c|}{$5 \mathrm{~W}+1 \mathrm{H}$} & \multicolumn{1}{|c|}{ Hasil Analisis } \\
\hline $\begin{array}{l}\text { Bagaimana model } \\
\text { penyampaian pesan anti } \\
\text { bullying yang mengena } \\
\text { untuk anak-anak? }\end{array}$ & $\begin{array}{l}\text { Berdasarkan hasil wawancara kepada psikolog anak, pesan } \\
\text { edukasi anti bullying yang mengena kepada anak-anak dapat } \\
\text { dikemas dalam bentuk studi kasus atau cerita yang dapat } \\
\text { menyentuh emosi dan empati anak-anak. }\end{array}$ \\
\hline $\begin{array}{l}\text { Bagaimana model } \\
\text { pembelajaran kreatif yang } \\
\text { digunakan di sekolah? }\end{array}$ & $\begin{array}{l}\text { Berdasarkan hasil wawancara kepada guru Sekolah Dasar di } \\
\text { Surabaya, model pembelajaran kreatif yang digunakan di } \\
\text { sekolah adalah dengan cara mendongeng, memutarkan video } \\
\text { kisah nyata yang lebih dapat menyentuh empati siswa-siswi. }\end{array}$ \\
\cline { 2 - 2 } & $\begin{array}{l}\text { Berdasarkan hasil wawancara kepada dua siswa-siswi yang } \\
\text { bersekolah di Sekolah Dasar Swasta dan Sekolah Dasar Negeri } \\
\text { di Surabaya, guru pernah mengajar dengan menggunakan cara } \\
\text { yang lebih menarik di sekolah, seperti menggunakan teknik } \\
\text { kolase dan mendongeng. }\end{array}$ \\
\hline
\end{tabular}

Setelah menganalisis dengan menggunakan rumusan kalimat tanya $5 \mathrm{~W}+1 \mathrm{H}$, selanjutnya adalah menyusun konsep kreatif pesan anti bullying yang disampaikan kepada anak Sekolah Dasar, sebagai berikut:

1. Terdapat pengkategorian perilaku bullying yang sering dilakukan oleh anak-anak di sekolah, yakni kategori perilaku bullying dengan bobot yang ringan, sedang, dan berat.

2. Setiap kategori perilaku bullying tersebut memiliki 5 studi kasus, sehingga jika ditotal secara keseluruhan terdapat 15 studi kasus.

3. Setiap studi kasus dikemas dalam bentuk pertanyaan dengan 3 pilihan jawaban di setiap pertanyan tersebut. 3 pilihan jawaban bernilai positif yakni merupakan sikap anti bullying yang dapat dilakukan oleh anak-anak jika melihat kejadian bullying di lingkungan sekolah.

4. Setiap pilihan jawaban di setiap pertanyaan memiliki nilai yang berbeda yakni 1,2 , dan 3. Nilai ini diterjemahkan sebagai poin yang diperoleh oleh anak-anak saat bermain dan akan diketahui totalnya di akhir permainan.

5. Jika anak-anak memperoleh total poin 15 (poin minimal), maka dianggap memiliki sikap anti bullying yang rendah, jika anak-anak memperoleh total poin 15-30, maka dianggap memiliki sikap anti bullying yang sedang, dan jika anak-anak memperoleh total poin 30-45, maka dianggap memiliki sikap anti bullying yang tinggi. Total poin ini juga akan menjadi reward pada board game.

Konsep kreatif pesan anti bullying yang disampaikan kepada anak Sekolah Dasar dapat dilihat pada Tabel 2 berupa draft copy write edukasi anti bullying. 
Tabel 2. Draft Copy Write Edukasi Anti Bullying [Sumber: Dokumentasi Penulis]

\begin{tabular}{|c|c|c|c|c|c|}
\hline No & $\begin{array}{l}\text { Bobot } \\
\text { Perilaku } \\
\text { Bullying }\end{array}$ & $\begin{array}{l}\text { Bentuk } \\
\text { Perilaku } \\
\text { Bullying }\end{array}$ & $\begin{array}{c}\text { Studi Kasus } \\
\text { Perilaku Bullying di } \\
\text { Lingkungan Sekolah } \\
\text { (Pertanyaan) }\end{array}$ & $\begin{array}{c}\text { Pilihan Jawaban } \\
\text { (Sikap Anti Bullying) }\end{array}$ & $\begin{array}{l}\text { Nilai } \\
\text { Jawaban } \\
\text { (Poin) }\end{array}$ \\
\hline \multirow[t]{3}{*}{1.} & \multirow[t]{3}{*}{ Ringan } & \multirow[t]{3}{*}{$\begin{array}{l}\text { Memilih-milih } \\
\text { teman } \\
\text { bermain }\end{array}$} & \multirow{3}{*}{$\begin{array}{l}\text { Temanmu selalu } \\
\text { menyendiri dan } \\
\text { murung di dalam } \\
\text { kelas, tidak ada } \\
\text { yang mau bermain } \\
\text { bersamanya karena } \\
\text { seragamnya lusuh. } \\
\text { Apa yang akan } \\
\text { kamu lakukan? }\end{array}$} & $\begin{array}{l}\text { Aku akan mengajak temanku } \\
\text { bermain, tapi aku takut kalau } \\
\text { aku juga akan dijauhi oleh } \\
\text { teman-teman lainnya. }\end{array}$ & 1 \\
\hline & & & & $\begin{array}{l}\text { Aku akan mengajak temanku } \\
\text { bermain tanpa peduli apakah } \\
\text { aku akan dijauhi oleh teman- } \\
\text { teman lainnya atau tidak. }\end{array}$ & 2 \\
\hline & & & & $\begin{array}{l}\text { Aku akan mengajak temanku } \\
\text { bermain dan mengajak teman- } \\
\text { teman lainnya untuk mau } \\
\text { bermain bersamanya. }\end{array}$ & 3 \\
\hline \multirow[t]{3}{*}{2.} & \multirow[t]{3}{*}{ Ringan } & \multirow{3}{*}{$\begin{array}{l}\text { Membuat } \\
\text { teman rendah } \\
\text { diri }\end{array}$} & \multirow{3}{*}{$\begin{array}{l}\text { Waktu pelajaran } \\
\text { berlangsung, Ibu } \\
\text { guru meminta } \\
\text { temanmu untuk } \\
\text { maju ke depan } \\
\text { kelas, tetapi } \\
\text { temanmu tidak } \\
\text { percaya diri karena } \\
\text { takut diolok-olok } \\
\text { oleh teman-teman } \\
\text { kelasmu. } \\
\text { Apa yang akan } \\
\text { kamu lakukan? }\end{array}$} & $\begin{array}{l}\text { Aku akan meminta Ibu guru } \\
\text { untuk meyakinkan temanku. }\end{array}$ & 1 \\
\hline & & & & $\begin{array}{l}\text { Aku akan meyakinkan } \\
\text { temanku dan memberikannya } \\
\text { semangat untuk maju ke } \\
\text { depan kelas. }\end{array}$ & 2 \\
\hline & & & & $\begin{array}{l}\text { Aku akan meyakinkan } \\
\text { temanku, memberikannya } \\
\text { semangat, dan membantunya } \\
\text { kalau dia ada kesulitan. }\end{array}$ & 3 \\
\hline \multirow[t]{3}{*}{3.} & \multirow[t]{3}{*}{ Ringan } & \multirow[t]{3}{*}{$\begin{array}{l}\text { Mengejek dan } \\
\text { membuat } \\
\text { teman rendah } \\
\text { diri }\end{array}$} & \multirow{3}{*}{$\begin{array}{l}\text { Di sekolahmu ada } \\
\text { temanmu yang } \\
\text { merasa sedih dan } \\
\text { tidak percaya diri } \\
\text { karena teman- } \\
\text { teman lain } \\
\text { memangilnya } \\
\text { gendut. } \\
\text { Apa yang akan } \\
\text { kamu lakukan? }\end{array}$} & $\begin{array}{l}\text { Aku akan menegur teman- } \\
\text { teman yang mengolok-olok, } \\
\text { tapi aku takut kalau mereka } \\
\text { akan menjauhiku. }\end{array}$ & 1 \\
\hline & & & & $\begin{array}{l}\text { Aku akan mengatakan kepada } \\
\text { temanku untuk selalu percaya } \\
\text { diri dan tidak menghiraukan } \\
\text { olokan teman-teman lain. }\end{array}$ & 2 \\
\hline & & & & $\begin{array}{l}\text { Aku akan mengatakan kepada } \\
\text { temanku untuk selalu percaya } \\
\text { diri dan menegur teman- } \\
\text { teman yang sudah mengolok- } \\
\text { olok. }\end{array}$ & 3 \\
\hline \multirow[t]{2}{*}{4.} & \multirow[t]{2}{*}{ Ringan } & \multirow[t]{2}{*}{$\begin{array}{l}\text { Menjahili } \\
\text { teman }\end{array}$} & \multirow{2}{*}{$\begin{array}{l}\text { Ada salah satu } \\
\text { teman yang selalu } \\
\text { usil kepada teman- } \\
\text { teman di kelas, } \\
\text { hingga teman- } \\
\text { teman banyak yang } \\
\text { menjauhinya. }\end{array}$} & $\begin{array}{l}\text { Aku akan menceritakan } \\
\text { kepada Bapak atau Ibu guru } \\
\text { kalau ada teman yang usil di } \\
\text { kelas. }\end{array}$ & 1 \\
\hline & & & & $\begin{array}{l}\text { Aku akan menegur temanku } \\
\text { yang usil dan mengajaknya } \\
\text { bermain bersamaku. }\end{array}$ & 2 \\
\hline
\end{tabular}




\begin{tabular}{|c|c|c|c|c|c|}
\hline No & $\begin{array}{l}\text { Bobot } \\
\text { Perilaku } \\
\text { Bullying }\end{array}$ & $\begin{array}{l}\text { Bentuk } \\
\text { Perilaku } \\
\text { Bullying }\end{array}$ & $\begin{array}{c}\text { Studi Kasus } \\
\text { Perilaku Bullying di } \\
\text { Lingkungan Sekolah } \\
\text { (Pertanyaan) } \\
\end{array}$ & $\begin{array}{c}\text { Pilihan Jawaban } \\
\text { (Sikap Anti Bullying) }\end{array}$ & $\begin{array}{l}\text { Nilai } \\
\text { Jawaban } \\
\text { (Poin) }\end{array}$ \\
\hline & & & $\begin{array}{l}\text { Apa yang akan } \\
\text { kamu lakukan? }\end{array}$ & $\begin{array}{l}\text { Aku akan menegur temanku } \\
\text { yang usil dan mengajak teman- } \\
\text { teman sekelasku untuk tidak } \\
\text { menjauhinya dan mau } \\
\text { bermain bersamanya karena } \\
\text { dia juga teman kita. }\end{array}$ & 3 \\
\hline \multirow[t]{3}{*}{5.} & \multirow[t]{3}{*}{ Ringan } & \multirow[t]{3}{*}{$\begin{array}{l}\text { Mengejek } \\
\text { teman }\end{array}$} & \multirow{3}{*}{$\begin{array}{l}\text { Setiap kali Ibu guru } \\
\text { memberikan tugas } \\
\text { tentang } \\
\text { menceritakan } \\
\text { keluarga dan } \\
\text { menyebutkan nama } \\
\text { orang tua, teman- } \\
\text { teman seringkali } \\
\text { menjadikan nama } \\
\text { orang tua sebagai } \\
\text { bahan ejekan. } \\
\text { Apa yang akan } \\
\text { kamu lakukan? }\end{array}$} & $\begin{array}{l}\text { Aku akan mengingatkan } \\
\text { teman-teman yang mengejek, } \\
\text { tapi aku takut kalau aku akan } \\
\text { menjadi sasaran ejekan } \\
\text { mereka. }\end{array}$ & 1 \\
\hline & & & & $\begin{array}{l}\text { Aku akan mengingatkan } \\
\text { teman-teman kalau kita tidak } \\
\text { boleh menjadikan nama orang } \\
\text { tua sebagai bahan ejekan. }\end{array}$ & 2 \\
\hline & & & & $\begin{array}{l}\text { Aku akan mengingatkan } \\
\text { teman-teman kalau kita tidak } \\
\text { boleh mengejek dan harus } \\
\text { menghormati orang yang lebih } \\
\text { tua dari kita meskipun bukan } \\
\text { orang tua kita. }\end{array}$ & 3 \\
\hline \multirow[t]{3}{*}{6.} & \multirow[t]{3}{*}{ Sedang } & \multirow[t]{3}{*}{$\begin{array}{l}\text { Memamerkan } \\
\text { barang kepada } \\
\text { teman }\end{array}$} & \multirow{3}{*}{$\begin{array}{l}\text { Ada salah satu } \\
\text { temanmu yang } \\
\text { suka pamer dengan } \\
\text { barang-barang } \\
\text { barunya hingga } \\
\text { membuat teman- } \\
\text { teman iri dan sedih } \\
\text { karena tidak bisa } \\
\text { memiliki barang itu. } \\
\text { Apa yang akan } \\
\text { kamu lakukan? }\end{array}$} & $\begin{array}{l}\text { Aku akan mengingatkan } \\
\text { temanku untuk tidak pamer } \\
\text { lagi, tapi aku takut kalau dia } \\
\text { tersinggung dan memusuhiku. }\end{array}$ & 1 \\
\hline & & & & $\begin{array}{l}\text { Aku akan mengingatkan } \\
\text { temanku untuk tidak pamer } \\
\text { lagi. }\end{array}$ & 2 \\
\hline & & & & $\begin{array}{l}\text { Aku akan mengingatkan } \\
\text { temanku untuk tidak pamer } \\
\text { lagi, mau berbagi, dan } \\
\text { meminjamkan barangnya } \\
\text { kepada teman lain. }\end{array}$ & 3 \\
\hline \multirow[t]{3}{*}{7.} & \multirow[t]{3}{*}{ Sedang } & \multirow[t]{3}{*}{$\begin{array}{l}\text { Berbohong } \\
\text { dan } \\
\text { menyalahkan } \\
\text { teman }\end{array}$} & \multirow{3}{*}{$\begin{array}{l}\text { Kamu melihat ada } \\
\text { dua temanmu yang } \\
\text { sedang bertengkar } \\
\text { karena berebut alat } \\
\text { tulis, hingga lbu } \\
\text { guru datang untuk } \\
\text { melerai. Salah satu } \\
\text { temanmu tidak } \\
\text { ingin disalahkan } \\
\text { dan tidak berbicara } \\
\text { jujur kepada Ibu } \\
\text { guru. } \\
\text { Apa yang akan } \\
\text { kamu lakukan? }\end{array}$} & $\begin{array}{l}\text { Aku akan menceritakan } \\
\text { kepada Ibu guru apa yang } \\
\text { sebenarnya terjadi, tapi aku } \\
\text { takut kalau setelah itu dia akan } \\
\text { memusuhiku. }\end{array}$ & 1 \\
\hline & & & & $\begin{array}{l}\text { Aku akan menegur temanku } \\
\text { untuk berbicara jujur kepada } \\
\text { lbu guru setelah kejadian itu. }\end{array}$ & 2 \\
\hline & & & & $\begin{array}{l}\text { Aku akan menceritakan } \\
\text { kepada Ibu guru apa yang } \\
\text { sebenarnya terjadi. }\end{array}$ & 3 \\
\hline
\end{tabular}




\begin{tabular}{|c|c|c|c|c|c|}
\hline No & $\begin{array}{l}\text { Bobot } \\
\text { Perilaku } \\
\text { Bullying }\end{array}$ & $\begin{array}{l}\text { Bentuk } \\
\text { Perilaku } \\
\text { Bullying }\end{array}$ & $\begin{array}{l}\text { Studi Kasus } \\
\text { Perilaku Bullying di } \\
\text { Lingkungan Sekolah } \\
\text { (Pertanyaan) }\end{array}$ & $\begin{array}{c}\text { Pilihan Jawaban } \\
\text { (Sikap Anti Bullying) }\end{array}$ & $\begin{array}{l}\text { Nilai } \\
\text { Jawaban } \\
\text { (Poin) }\end{array}$ \\
\hline \multirow[t]{3}{*}{8.} & \multirow[t]{3}{*}{ Sedang } & \multirow[t]{3}{*}{$\begin{array}{l}\text { Meminjam } \\
\text { barang teman } \\
\text { tanpa izin }\end{array}$} & \multirow{3}{*}{$\begin{array}{l}\text { Di kelasmu ada } \\
\text { salah satu teman } \\
\text { yang meminjam } \\
\text { barang milik teman } \\
\text { lain tanpa izin. } \\
\text { Apa yang akan } \\
\text { kamu lakukan? }\end{array}$} & $\begin{array}{l}\text { Aku akan mengingatkan } \\
\text { temanku untuk meminta izin } \\
\text { saat meminjam barang, tapi } \\
\text { kan itu bukan barangku. }\end{array}$ & 1 \\
\hline & & & & $\begin{array}{l}\text { Aku akan mengingatkan } \\
\text { temanku yang sudah } \\
\text { meminjam barang tanpa izin } \\
\text { meskipun itu bukan barangku. }\end{array}$ & 2 \\
\hline & & & & $\begin{array}{l}\text { Aku akan mengingatkan } \\
\text { temanku untuk meminta maaf } \\
\text { dan tidak akan mengulanginya } \\
\text { lagi. }\end{array}$ & 3 \\
\hline \multirow[t]{3}{*}{9.} & \multirow[t]{3}{*}{ Sedang } & \multirow[t]{3}{*}{$\begin{array}{l}\text { Merusak } \\
\text { barang teman }\end{array}$} & \multirow{3}{*}{$\begin{array}{l}\text { Salah satu } \\
\text { temanmu suka } \\
\text { sekali merusak } \\
\text { barang teman lain, } \\
\text { tapi tidak mau } \\
\text { bertanggung jawab. } \\
\text { Apa yang akan } \\
\text { kamu lakukan? }\end{array}$} & $\begin{array}{l}\text { Aku akan mengingatkan } \\
\text { temanku untuk tidak merusak } \\
\text { barang teman lain, tapi kan itu } \\
\text { bukan barangku. }\end{array}$ & 1 \\
\hline & & & & $\begin{array}{l}\text { Aku akan mengingatkan } \\
\text { temanku untuk meminta maaf } \\
\text { dan tidak akan mengulanginya } \\
\text { lagi. }\end{array}$ & 2 \\
\hline & & & & $\begin{array}{l}\text { Aku akan mengingatkan } \\
\text { temanku untuk meminta maaf } \\
\text { dan mengganti barang yang } \\
\text { dirusak. }\end{array}$ & 3 \\
\hline \multirow[t]{3}{*}{10.} & \multirow[t]{3}{*}{ Sedang } & \multirow[t]{3}{*}{$\begin{array}{l}\text { Mengganggu } \\
\text { dan memaksa } \\
\text { teman }\end{array}$} & \multirow{3}{*}{$\begin{array}{l}\text { Saat ulangan harian } \\
\text { ada temanku yang } \\
\text { selalu saja diganggu } \\
\text { oleh teman lain dan } \\
\text { memaksa untuk } \\
\text { mencontek } \\
\text { jawabannya. } \\
\text { Apa yang akan } \\
\text { kamu lakukan? }\end{array}$} & $\begin{array}{l}\text { Aku akan mengatakan kepada } \\
\text { temanku untuk mengabaikan } \\
\text { teman yang mencontek. }\end{array}$ & 1 \\
\hline & & & & $\begin{array}{l}\text { Aku akan melaporkan kejadian } \\
\text { ini kepada Bapak atau Ibu } \\
\text { guru. }\end{array}$ & 2 \\
\hline & & & & $\begin{array}{l}\text { Aku akan mengatakan kepada } \\
\text { temanku untuk menolaknya } \\
\text { dan menegur temanku yang } \\
\text { mencontek kalau itu } \\
\text { perbuatan yang tidak baik. }\end{array}$ & 3 \\
\hline \multirow[t]{3}{*}{11.} & \multirow[t]{3}{*}{ Berat } & \multirow{3}{*}{$\begin{array}{l}\text { Membuat } \\
\text { teman } \\
\text { ketakutan }\end{array}$} & \multirow{3}{*}{$\begin{array}{l}\text { Saat kamu akan ke } \\
\text { kamar mandi, kamu } \\
\text { melihat beberapa } \\
\text { temanmu } \\
\text { mengunci pintu } \\
\text { kamar mandi } \\
\text { teman lain yang } \\
\text { berada di dalamnya } \\
\text { hingga ketakutan. } \\
\text { Apa yang akan } \\
\text { kamu lakukan? }\end{array}$} & $\begin{array}{l}\text { Aku akan menolong temanku } \\
\text { saat mereka sudah pergi. }\end{array}$ & 1 \\
\hline & & & & $\begin{array}{l}\text { Aku akan melaporkan kejadian } \\
\text { ini kepada Bapak atau Ibu } \\
\text { guru. }\end{array}$ & 2 \\
\hline & & & & $\begin{array}{l}\text { Aku akan menghentikan } \\
\text { tindakan ini dan menegur } \\
\text { mereka. }\end{array}$ & 3 \\
\hline
\end{tabular}




\begin{tabular}{|c|c|c|c|c|c|}
\hline No & $\begin{array}{l}\text { Bobot } \\
\text { Perilaku } \\
\text { Bullying }\end{array}$ & $\begin{array}{l}\text { Bentuk } \\
\text { Perilaku } \\
\text { Bullying }\end{array}$ & $\begin{array}{c}\text { Studi Kasus } \\
\text { Perilaku Bullying di } \\
\text { Lingkungan Sekolah } \\
\text { (Pertanyaan) } \\
\end{array}$ & $\begin{array}{c}\text { Pilihan Jawaban } \\
\text { (Sikap Anti Bullying) }\end{array}$ & $\begin{array}{l}\text { Nilai } \\
\text { Jawaban } \\
\text { (Poin) }\end{array}$ \\
\hline \multirow[t]{3}{*}{12.} & \multirow[t]{3}{*}{ Berat } & \multirow[t]{3}{*}{$\begin{array}{l}\text { Menjebak } \\
\text { teman }\end{array}$} & \multirow{3}{*}{$\begin{array}{l}\text { Temanmu } \\
\text { menangis } \\
\text { seragamnya basah } \\
\text { kuyub tersiram air } \\
\text { karena dijebak oleh } \\
\text { beberapa teman di } \\
\text { kelas. } \\
\text { Apa yang akan } \\
\text { kamu lakukan? }\end{array}$} & $\begin{array}{l}\text { Aku akan membantu temanku } \\
\text { untuk mengeringkan } \\
\text { seragamnya. }\end{array}$ & 1 \\
\hline & & & & $\begin{array}{l}\text { Aku akan membantu temanku } \\
\text { dan melaporkan kejadian ini } \\
\text { kepada Bapak atau Ibu guru. }\end{array}$ & 2 \\
\hline & & & & $\begin{array}{l}\text { Aku akan membantu temanku } \\
\text { dan menegur teman-teman } \\
\text { yang menjebak untuk } \\
\text { meminta maaf dan tidak } \\
\text { mengulanginya lagi. }\end{array}$ & 3 \\
\hline \multirow[t]{3}{*}{13.} & \multirow[t]{3}{*}{ Berat } & \multirow[t]{3}{*}{$\begin{array}{l}\text { Menyakiti fisik } \\
\text { teman }\end{array}$} & \multirow{3}{*}{$\begin{array}{l}\text { Tangan temanmu } \\
\text { sakit sekali karena } \\
\text { ada teman lain } \\
\text { yang memukulnya } \\
\text { tanpa sebab. } \\
\text { Apa yang akan } \\
\text { kamu lakukan? }\end{array}$} & $\begin{array}{l}\text { Aku akan membiarkan teman } \\
\text { yang memukul dan meminta } \\
\text { temanku untuk tidak } \\
\text { membalasnya karena itu akan } \\
\text { menyakiti. }\end{array}$ & 1 \\
\hline & & & & $\begin{array}{l}\text { Aku akan mengingatkan } \\
\text { kepada teman yang memukul } \\
\text { untuk meminta maaf kepada } \\
\text { temanku karena telah } \\
\text { menyakiti. }\end{array}$ & 2 \\
\hline & & & & $\begin{array}{l}\text { Aku akan mengingatkan } \\
\text { kepada teman yang memukul } \\
\text { untuk meminta maaf dan } \\
\text { melaporkan kejadian ini } \\
\text { kepada Bapak atau Ibu guru. }\end{array}$ & 3 \\
\hline \multirow[t]{3}{*}{14.} & \multirow[t]{3}{*}{ Berat } & \multirow[t]{3}{*}{$\begin{array}{l}\text { Menyakiti fisik } \\
\text { teman }\end{array}$} & \multirow{3}{*}{$\begin{array}{l}\text { Temanmu } \\
\text { kesakitan ketika } \\
\text { jatuh dan lututnya } \\
\text { berdarah karena } \\
\text { ada teman lain } \\
\text { yang } \\
\text { mendorongnya. } \\
\text { Apa yang akan } \\
\text { kamu lakukan? }\end{array}$} & $\begin{array}{l}\text { Aku akan menolong temanku } \\
\text { ke UKS. }\end{array}$ & 1 \\
\hline & & & & $\begin{array}{l}\text { Aku akan menolong temanku } \\
\text { dan menegur teman yang } \\
\text { mendorong. }\end{array}$ & 2 \\
\hline & & & & $\begin{array}{l}\text { Aku akan menolong temanku } \\
\text { dan melaporkan kejadian ini } \\
\text { kepada Bapak atau Ibu guru. }\end{array}$ & 3 \\
\hline \multirow[t]{3}{*}{15.} & \multirow[t]{3}{*}{ Berat } & \multirow[t]{3}{*}{$\begin{array}{l}\text { Mengambil } \\
\text { barang teman }\end{array}$} & \multirow{3}{*}{$\begin{array}{l}\text { Temanmu bersedih } \\
\text { karena uang } \\
\text { sakunya diambil } \\
\text { oleh teman lain dan } \\
\text { tidak bisa membeli } \\
\text { makan siang. } \\
\text { Apa yang akan } \\
\text { kamu lakukan? }\end{array}$} & $\begin{array}{l}\text { Aku akan membelikan } \\
\text { makanan untuk temanku, tapi } \\
\text { uangku tidak cukup. }\end{array}$ & 1 \\
\hline & & & & $\begin{array}{l}\text { Aku akan menegur teman yang } \\
\text { mengambil uang untuk } \\
\text { mengembalikan uang yang } \\
\text { bukan miliknya. }\end{array}$ & 2 \\
\hline & & & & $\begin{array}{l}\text { Aku akan membeli makanan } \\
\text { dan berbagi dengan temanku, } \\
\text { kemudian melaporkan } \\
\text { kejadian ini kepada Bapak atau } \\
\text { lbu guru. }\end{array}$ & 3 \\
\hline
\end{tabular}


Keyword visual yang disusun dalam penelitian adalah "Fun Positive Learning". Makna "Fun" mewakili board game yang merupakan media edukasi menyenangkan untuk dimainkan oleh anak-anak. Sedangkan "Positive Learning" merupakan pembelajaran positif mengenai edukasi anti bullying yang dikemas dalam story board game. Keyword Fun Positive Learning akan diterapkan pada desain komponen-komponen board game.

\subsection{Konsep Perancangan Board Game}

Board game Berani Baik! merupakan board game yang harus dimainkan bersama (tim) dengan jumlah pemain minimal 3 orang ( 2 orang sebagai pemain dan 1 orang sebagai pemandu) dan maksimal 4 orang ( 3 orang sebagai pemain dan 1 orang sebagai pemandu). Durasi waktu board game Berani Baik! adalah 30-45 menit untuk sekali bermain dengan alur permainan adalah sebagai berikut:

a. Permainan dimulai dari pemain pertama dan berlanjut sesuai arah jarum jam, setiap pemain akan mendapat giliran hingga permainan selesai. Seluruh pemain dapat menentukan siapa pemain pertama dengan berbagai cara yang telah disepakati bersama.

b. Pemain yang mendapat giliran bermain harus melempar dadu untuk menentukan seberapa jauh jumlah langkah agar pion dapat bergerak ke arah pos-pos yang dituju.

c. Selama permainan berlangsung, setiap pemain bebas memilih pos-pos yang akan dituju selama tidak terdapat pemain lain yang berada pada pos tersebut.

d. Pemberhentian di setiap pos ditandai dengan adanya titik lokasi berwarna merah dan nomor pos yang berada di dekat pos. Pada titik tersebut, pion dapat berhenti sebagai tanda bahwa pos masih ditempati.

e. Setiap pemain harus menyelesaikan misi pada 15 pos dan setiap pemain hanya diperbolehkan menempati atau menyelesaikan 1 pos sebanyak 1 kali.

f. Setiap pos terdapat misi yang berisi pertanyaan dan jawaban yang harus diselesaikan oleh pemain. Pemain tidak perlu takut menjawab di setiap pertanyaan, karena tidak ada jawaban yang salah dan pemain akan mendapatkan poin di setiap jawaban.

g. Pertanyaan dan jawaban yang dipilih oleh pemain harus diketahui oleh pemandu dalam permainan.

h. Setelah menyelesaikan misi di setiap pos, maka pemain harus memberikan tanda centang atau check list pada setiap kotak yang bertuliskan nomor-nomor pos yang berada pada board reward sesuai dengan nomor pos yang telah diselesaikan. Tanda centang berupa pin kecil yang akan diberikan oleh pemandu setelah pemain menyelesaikan misi di setiap pos.

i. Pemain dapat menambahkan poin kebaikan pada board reward sesuai dengan poin yang didapatkan oleh pemain di setiap jawaban.

j. Jika pemain telah menyelesaikan seluruh misi atau melewati seluruh pos (15 pos), maka pion pemain harus kembali lagi ke tempat awal mulai bermain yakni di tengah lapangan.

\subsection{Visualisasi Desain Board Game}

Judul board game edukasi anti bullying untuk anak Sekolah Dasar yang dirancang adalah "Berani Baik!". Judul Berani Baik! merupakan hasil brainstorming dari keyword Fun Positive Learning, yakni melalui board game Berani Baik! anak-anak akan memperoleh 
edukasi untuk berani menjadi pribadi yang baik dengan tidak melakukan tindakan bullying kepada teman dan berani bersikap positif "stop bullying" jika melihat kejadian bullying di lingkungan sekolah. Berikut pada Gambar 4 merupakan desain logo judul board game Berani Baik!

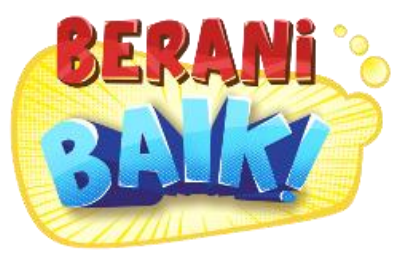

Gambar 4. Desain Logo Judul Board Game Berani Baik! [Sumber: Dokumentasi Penulis]

Desain pion pada board game Berani Baik! mengimplementasikan keyword Fun Positive Learning dengan menggunakan karakter anak-anak dengan karakteristik yang ceria dan ekspresif, seperti pada Gambar 5.

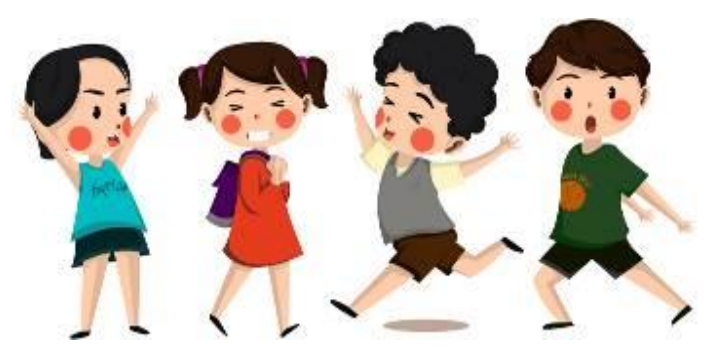

Gambar 5. Desain Pion Pada Board Game Berani Baik! [Sumber: Dokumentasi Penulis]

Board utama pada board game Berani Baik! dengan ukuran $50 \mathrm{~cm} \times 50 \mathrm{~cm}$ memiliki 15 pos mini (buku pos) yang berisi pertanyaan sebagai studi kasus perilaku bullying di lingkungan sekolah dan 3 pilihan jawaban sebagai pesan anti bullying kepada anak-anak. Berikut pada Gambar 6 merupakan desain board utama pada board game Berani Baik!.

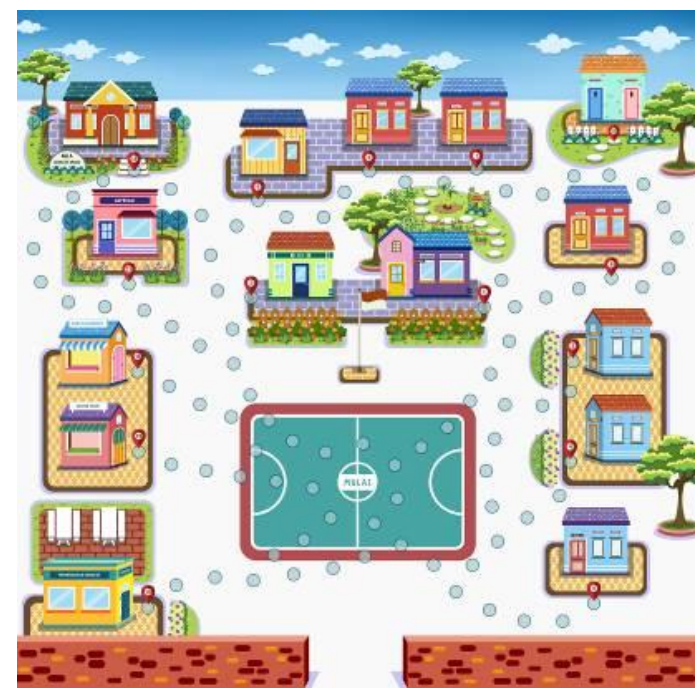

Gambar 6. Desain Board Utama Pada Board Game Berani Baik! [Sumber: Dokumentasi Penulis] 
Desain board utama pada board game Berani Baik! menggunakan visualisasi environment sekolah berupa ruangan-ruangan yang terdapat di sekolah, seperti ruang kelas, ruang koperasi, ruang kesenian, ruang Unit Kesehatan Siswa, ruang guru, dan sebagainya. Setiap ruangan memiliki kantong yang digunakan untuk mewadahi buku pos tersebut.

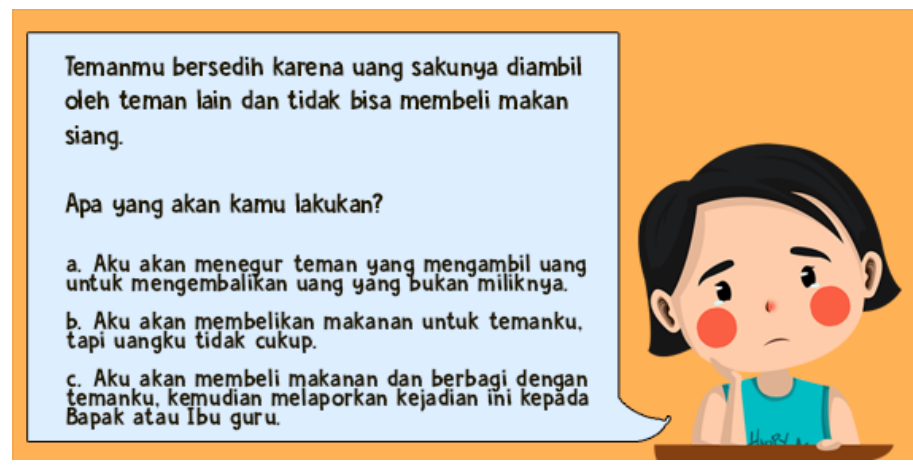

Gambar 7. Desain Buku Pos pada Board Game Berani Baik!

[Sumber: Dokumentasi pribadi]

Buku pos pada board game Berani Baik! berjumlah 15 buku pos yang berisi pertanyaan sebagai studi kasus perilaku bullying di lingkungan sekolah dan 3 pilihan jawaban sebagai pesan anti bullying kepada anak-anak. Desain buku pos pada board game Berani Baik seperti pada Gambar 7. Buku pos dapat dimasukkan ke dalam kantong yang tersedia pada board utama dengan mekanisme seperti pada Gambar 8.

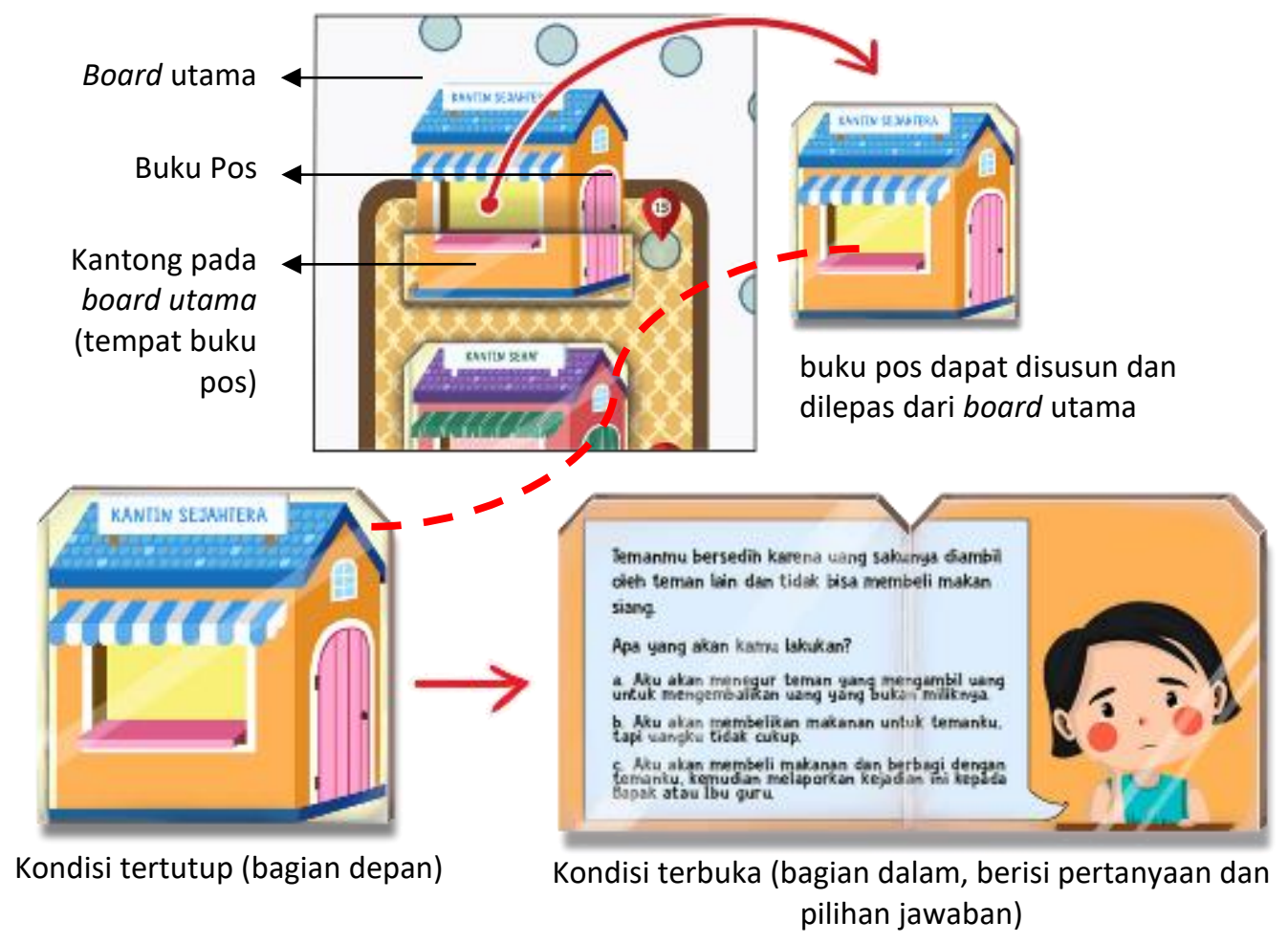

Gambar 8. Mekanisme Buku Pos pada Board Utama

[Sumber: Dokumentasi Penulis] 
Selanjutnya terdapat board reward dengan ukuran $20 \mathrm{~cm} \times 15 \mathrm{~cm}$ berjumlah empat buah yang merupakan board untuk menampung poin-poin dari setiap pilihan jawaban. Setiap pertanyaan memiliki 3 pilihan jawaban dengan poin yang berbeda, yakni 1, 2, dan 3 . Poin-poin yang diperoleh akan diketahui totalnya di akhir permainan. Pada board reward terdapat 3 wilayah range poin yang ditandai dengan warna yang berbeda (merah-kuning-hijau). Range poin 1-15 dengan warna merah yakni jika total poin yang diperoleh anak-anak adalah 15 (poin minimal) maka anak-anak dianggap memiliki sikap anti bullying yang rendah. Range poin 15-30 dengan warna kuning yakni jika total poin yang diperoleh adalah 15-30 maka anak-anak dianggap memiliki sikap anti bullying yang sedang. Range poin 30-45 dengan warna kuning yakni jika total poin yang diperoleh adalah 30-45 maka anak-anak dianggap memiliki sikap anti bullying yang tinggi.

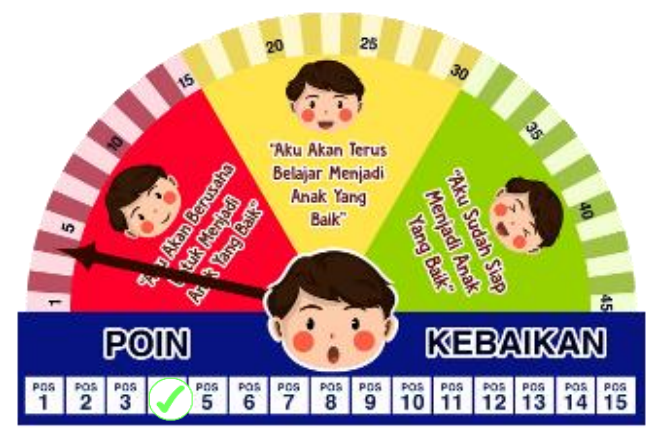

Gambar 9. Desain Board Reward

[Sumber: Dokumentasi Penulis]

Selain itu, pada bagian bawah board reward terdapat kotak yang bertuliskan nomornomor pos yang dapat diberikan pin kecil (pin tanda centang atau check list) sebagai tanda bahwa telah menjawab pertanyaan pada pos tersebut. Setiap anak diberikan 15 pin kecil untuk menandai 15 nomor pertanyaan. Desain board reward seperti pada Gambar 9. Sebagai petunjuk permainan, dibuat buku panduan board game Berani Baik! yang meliputi persiapan bermain, alur permainan, peraturan permainan, tugas pemandu, dan objektif permainan. Mock up desain buku panduan seperti pada Gambar 10.
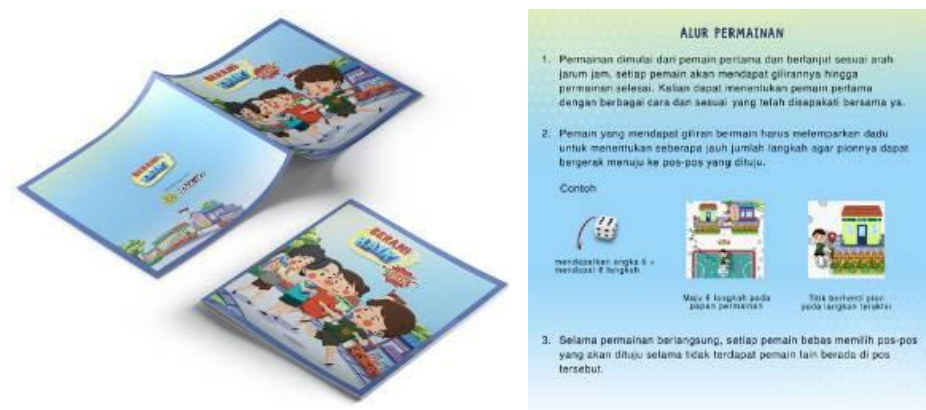

Gambar 10. Mock Up Desain Buku Panduan

[Sumber: Dokumentasi Penulis]

Buku pemandu berisi poin untuk setiap jawaban dari 15 pertanyaan. Selama permainan berlangsung, buku pemandu hanya boleh dipegang oleh pemandu. Mock up desain buku pemandu seperti pada Gambar 11. 


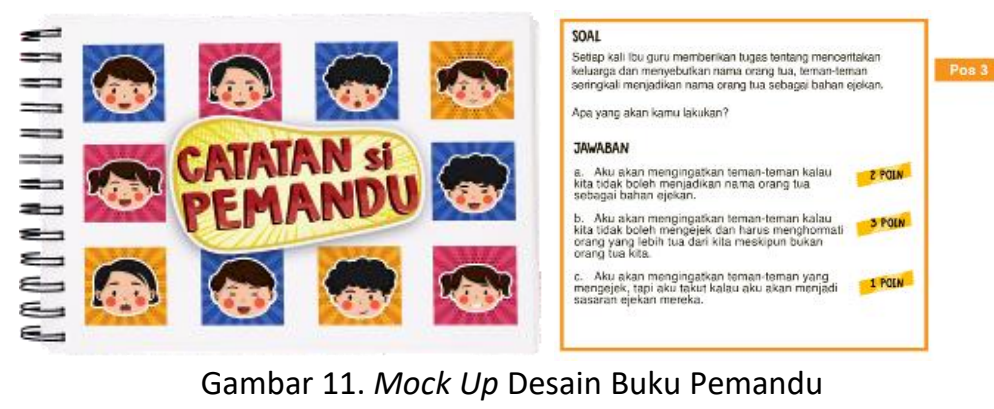

[Sumber: Dokumentasi Penulis]

Kemasan berbentuk box dengan ukuran $27 \mathrm{~cm} \times 27 \mathrm{~cm} \times 4 \mathrm{~cm}$ digunakan untuk mewadahi komponen-komponen board game agar tidak terpisah dan tidak hilang. Mock up desain kemasan board game seperti pada gambar 12 .

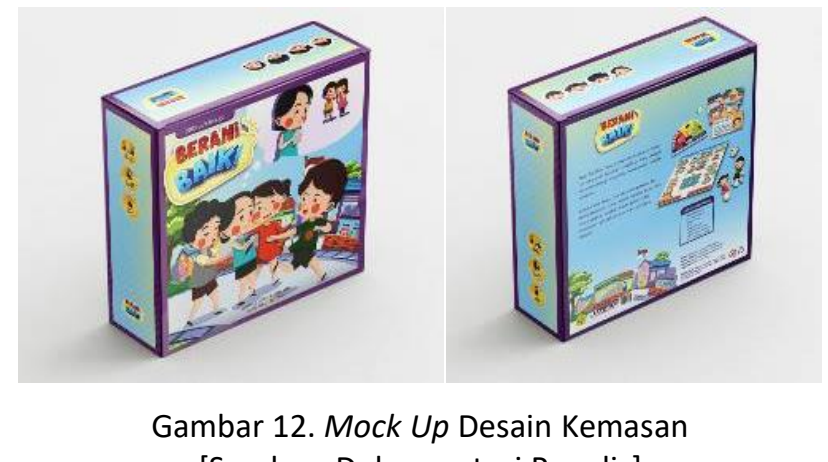

[Sumber: Dokumentasi Penulis]

\section{KESIMPULAN}

Board game edukasi anti bullying dengan judul Berani Baik! dirancang dengan latar belakang semakin meningkatnya kasus bullying di Indonesia dan menjadi masalah sosial yang serius terutama di kalangan anak Sekolah Dasar yang menjadi mayoritas terjadinya kasus bullying. Board game Berani Baik! dirancang dengan alur permainan yang menyenangkan sebagai edukasi anti bullying kepada anak Sekolah Dasar yang dikemas dalam bentuk pertanyaan dengan jumlah 15 pertanyaan sebagai studi kasus perilaku bullying di lingkungan sekolah dan 3 pilihan jawaban sebagai pesan anti bullying kepada anak Sekolah Dasar. Board game Berani Baik! juga memiliki visual yang menarik bagi anak Sekolah Dasar yakni pada komponen-komponen board game, seperti pion, board utama, board reward, buku pos, dan kemasan. Board game Berani Baik! diharapkan dapat mempersuasi anak-anak untuk berani bersikap positif "stop bullying" jika melihat kejadian bullying di lingkungan sekolah.

\section{DAFTAR PUSTAKA}

Coloroso, B. 2006. Penindas, Tertindas, dan Penonton, Resep Memutus Rantai Kekerasan Anak dari Prasekolah Hingga SMU. Jakarta: Serambi.

Criswell, Patti Kelley. 2009. Stand Up for Yourself \& Your Friends: Dealing with Bullies and Bossiness, and Finding a Better Way. American Girl. 
Daymon, Christine \& Holloway, Immy. 2002. Qualitative Research Methods in Public Relations \& Marketing Communications. Terjemahan: Cahya Wiratama. Bandung: Mizan Media Utama.

Hasan, M. Iqbal. 2002. Pokok-pokok Materi Metodologi Penelitian dan Aplikasinya. Bogor: Ghalia Indonesia.

Hendrian, Dedi. 2018. KPAl: Perundungan Urutan Keempat Kasus Kekerasan Anak. https://www.kpai.go.id/publikasi/kpai-perundungan-urutan-keempat-kasuskekerasan-anak. Diakses pada 20 November 2020 pukul 19.00.

Instagram KPAI_Official. 28 Januari 2020. Anak Menjadi Korban Bullying?. Dipetik pada tanggal 20 November 2020 dari https://www.instagram.com/p/B724XISn58g/.

Misrah. 2013. Peningkatan Kemampuan Siswa Membuat Kalimat Tanya Melalui Teknik 5W $1 \mathrm{H}$ di Kelas IV SD Inpres Lobu Gio. Jurnal Kreatif Tadulako Online, Vol.1, No.4.

Najib, Amanu. 2018. Pengembangan Media Pembelajaran Board Game Berbasis Augmented Reality Pada Mata Pelajaran Teknik Dasar Listrik dan Elektronika di Sekolah Menengah Kejuruan. E-Journal UNY, Vol.8, No.1.

Santrock, J. W. 2009. Masa Perkembangan Anak. Jakarta: Salemba Humanika.

Sarwono, Jonathan \& Lubis, Hary. 2007. Metode Riset Untuk Desain Komunikasi Visual. Yogyakarta: Andi.

Soefandi, Indra. 2015. Strategi Mengembangkan Potensi Kecerdasan Anak. Jakarta: Bee Media Indonesia.

Undang-Undang No. 35 Tahun 2014 Tentang Perlindungan Anak (UU 35/2014) Pasal 76C.

Wibisono, Aryo Bayu. 2020. Riset Desain: Pengumpulan Data dan Analisa. Surabaya: Putra Media Nusantara.

Wiyani, Ardy. 2012. Save Our Children from School Bullying. Jogjakarta: Arruzz Media. 